\title{
Seed Piece Spacing for Spring Chipping Potato Cultivars in Florida
}

Fernanda Souza Krupek

Horticultural Sciences Department, University of Florida, 1241 Fifield Hall, Gainesville, FL 32611; and Luiz de Queiroz College of Agriculture, University of Sao Paulo, Piracicaba, SP, Brazil

\section{Christian T. Christensen}

Horticultural Sciences Department, University of Florida, 1241 Fifield Hall, Gainesville, FL 32611

\section{Charles E. Barrett}

University of Florida, Institute of Food and Agricultural Sciences, IFAS Extension, Live Oak, FL 32060

\section{Lincoln Zotarelli ${ }^{1}$ \\ Horticultural Sciences Department, University of Florida, 1241 Fifield Hall, Gainesville, FL 32611}

Additional index words. Atlantic, Harley Blackwell, Elkton, tuber yield, tuber marketable yield, tuber size distribution, economic analysis

\begin{abstract}
The cost of seed accounts for nearly $10 \%$ of the estimated production cost of chipping potato (Solanum tuberosum) production in Florida. Optimizing seed piece spacing can reduce costs without affecting potato yield. This study evaluated the effects of seed piece spacing on yield, quality, and economic revenue of chipping potato production in north Florida. A field experiment was conduct during the spring of 2013, 2014, and 2016 in Hastings, FL, with a split-plot randomized complete block design. In-row seed piece spacings of 10, 15, 20 (industry standard), 25 , and $30 \mathrm{~cm}$ were assigned as the main plot and $S$. tuberosum potato cultivars (Atlantic, Harley Blackwell, and Elkton) as the subplots. Marketable tuber yield ranged between 10.8 and $15.2 \mathrm{Mg} \cdot \mathrm{ha}^{-1}$ in 2013, 10.1 and 12.8 $\mathrm{Mg} \cdot \mathrm{ha}^{-1}$ in 2014, and 9.9 and 19.7 $\mathrm{Mg} \cdot \mathrm{ha}^{-1}$ in 2016. Overall lower yields in 2013 were due to three freeze events early in the season. Widening seed piece spacing resulted in a linear decrease in total and marketable yield in 2013 and 2014. Conversely, seed piece spacings of 10 and $15 \mathrm{~cm}$ showed lower marketable yields in 2016. There was no interaction between in-row spacing and cultivar in any year tested. Cultivars performed variably across years for total and marketable yield and specific gravity. Tuber specific gravity was unaffected by seed piece spacing, except in 2013, when 25 and $30 \mathrm{~cm}$ resulted in slightly higher values. There was no significant difference in total and marketable yield between the industry standard seed piece spacing 20 and $25 \mathrm{~cm}$ in any year. In-row spacing of $25 \mathrm{~cm}$ in 2013 and $30 \mathrm{~cm}$ seed piece spacing in 2014 and 2016 provided the greatest economic return. Net revenue can be increased by adjusting the in-row seed piece spacing from the commercial standard of 20 to $25 \mathrm{~cm}$, which reduces production cost without negatively impacting yields.
\end{abstract}

Florida is ranked as the seventh highestvalue potato ( $S$. tuberosum) producing state in the United States, producing one-third of

Received for publication 4 Oct. 2016. Accepted for publication 23 Nov. 2016.

We thank University of Florida, Hastings Agricultural Extension Center technicians Doug Gergela, Dana Burnham, Scott Taylor, Scott Chamber, Pam Solano, Bart Herrington, and Rodrick Mwatuwa for their assistance with field operations. We also acknowledge research fellowship from the Horticultural Sciences Department of the University of Florida and the Innovation Agency of the University of Sao Paulo, Brazil. This research was originally presented at the 2016 annual meeting of the Florida State Horticultural Society.

Mention of trade names or commercial products in this publication is solely for the purpose of providing specific information and does not imply recommendation or endorsement by the University of Florida. ${ }^{1}$ Corresponding author. E-mail: lzota@ufl.edu. the winter and spring crop. About $395 \mathrm{Mg}$ of potatoes are harvested annually on 11,900 ha in Florida valued at $\$ 131$ million (USDA, 2015 ). The chipping potato market represents $\approx 75 \%$ of the total potato marketplace in Florida. The cultivar Atlantic, released by the USDA in 1976 (Webb et al., 1978), is the most popular chipping potato cultivar in the United States; however, new chipping cultivars, such as Elkton (Haynes et al., 2014) and Harley Blackwell (Hutchinson et al., 2006), have shown promise under Florida's environmental conditions.

The current guidelines for seed piece spacing for potatoes in Florida ranges from 12.7 to $25.4 \mathrm{~cm}$ (Zotarelli et al., 2016), but do not consider the potato type (e.g., chipping, processing, or table stock). On a commercial farm, seed piece spacing directly affects the costs of the seed and indirectly affects operating expenses through costs associated with handling, storage, cultural practices, and transportation. Generally, a higher total tuber yield per area is reached with higher plant densities, hence closer in-row seed piece spacing practices have been adopted (Bussan et al., 2007). In contrast, a narrower seed piece spacing increases interplant competition for available nutrients, water, space, and sunlight (Mangani et al., 2015) and can reduce yield. The tuber yield response to seed piece spacing may be affected by several factors including the soil type, climatic conditions, or type of potatoes.

Identifying ideal in-row seed piece spacing among cultivars is necessary to optimize production efficiency. Bussan et al. (2007) observed an increase in tuber yield with increased potato plant density for 'Russet Burbank'. Creamer et al. (1999) reported that marketable tuber yield of 'Atlantic' decreased with a seed piece spacing greater than $23 \mathrm{~cm}$, whereas 'Superior' and 'Snowden' were less sensitive to differences in spacing. These results suggest that these cultivars differed in their ability to compensate for wider gaps as the plant population is reduced. Bohl et al. (2011) reported that the average tuber size (cm) of 'Alturas', 'Russet Norkotah', and 'Ranger Russet' was reduced at the 20 and $30 \mathrm{~cm}$ in-row spacing treatments when compared with the $40-\mathrm{cm}$ treatment. The lower plant density of the $40 \mathrm{~cm}$ in-row seed spacing reduced interplant competition and allowed to produce larger tubers.

Potato seed accounts for $\approx 10 \%$ of the total cost of production in Florida. Optimizing seed piece spacing to increase profits of potato production is a viable management strategy by reducing production costs associated with handling, storage, cultural practices, and transportation. An economic return analysis was conducted with a fresh-market potato cultivar Russet Norkotah planted using different in-row seed piece spacings (Bohl et al., 2011). Similar gross returns per hectare were achieved by planting at either 20 or $30 \mathrm{~cm}$ between seed pieces in that study. Conversely, the gross revenue of a $42 \mathrm{~g}$ seed piece planted at $20 \mathrm{~cm}$ was nearly $30 \%$ higher than at $40 \mathrm{~cm}$ (Bohl et al., 2011). Although these economic analyses highlight the potential to reduce seed cost by adjusting seed piece spacing, no studies have been conducted on chipping potato cultivars for Florida. Understanding and predicting the effect of seed piece spacing on tuber size distribution, yield, physiological disorders, and economic performance will help growers on their decision. The objective of the present study was to evaluate the effect of seed piece spacing on total and marketable tuber yield, tuber size distribution, and physiological disorders of three chipping potato cultivars: market standard (Atlantic) and two new chipping cultivars (Elkton and Harley Blackwell). A partial budget analysis was conducted to determine the net return of in-row spacing treatments. The analysis focused on seed cost and yield as a result of seed piece spacing. 


\section{Materials and Methods}

Location. The experimental trials were performed at University of Florida, Hastings Agricultural Extension Center, Hastings, FL $\left(29^{\circ} 41^{\prime} 27^{\prime \prime} \mathrm{N}, 81^{\circ} 26^{\prime} 31^{\prime \prime} \mathrm{W}\right)$ during the spring of 2013, 2014, and 2016. The soil was classified as sandy, siliceous, hyperthermic Arenic Ochraqualf belonging to the Ellzey series (USDA, 1983). The soil texture is sandy and the particle-size distribution in the topsoil is $94 \%$ sand, $2.5 \%$ silt, and $3.5 \%$ clay.

Experimental design. The experiment was conducted using a split-plot design with randomized complete blocks and four replications. Seed piece spacing treatments 10 , $15,20,25$, and $30 \mathrm{~cm}$ were assigned to the main plot. Three commercial chipping $S$. tuberosum potato cultivars Atlantic (market standard), Harley Blackwell (USDA, 2016), and Elkton (Haynes et al., 2014) were the subplots. All cultivars have similar maturity classified as medium to medium late, and when planted as spring crop under northeast Florida conditions, cultivars were expected to be harvested 90 to $100 \mathrm{~d}$ after planting (DAP). The main plot size was $30.3 \mathrm{~m}$ long $\times$ $4.08 \mathrm{~m}$ wide plots (four rows). Subplots were $10.1 \mathrm{~m}$ long and $8.1 \mathrm{~m}$ wide. Trials were planted 15 Jan. 2013, 17 Jan. 2014, and 21 Jan. 2016.

Management practices and fertilizer schedule. Water was supplied via seepage irrigation. The irrigation furrows were spaced $18 \mathrm{~m}$ apart and between each furrow, 16 hilled rows ( $0.35 \mathrm{~m}$ height) were formed with $1.02 \mathrm{~m}$ between row centers. Before planting, the field was fumigated with Telone ${ }^{\circledR} \mathrm{C}-35$ [1,3 dichloropropene $(64 \%)+$ chloropicrin (36\%); Dow AgroSciences, Indianapolis, IN] at a rate of $280 \mathrm{~kg} \cdot \mathrm{ha}^{-1}$. Fumigation was applied on 18 Dec. 2012, 17 Dec. 2013, and 21 Dec. 2015. Potato seeds were mechanically cut $(\approx 56 \mathrm{~g})$ and seed pieces were dusted with the Maxim (fludioxonil; Syngenta Crop Protection, Inc., Greensboro, NC) at a rate of $227 \mathrm{~g}$ of product per $45 \mathrm{~kg}$ of seed pieces. At planting, Quadris (azoxystrobin; Syngenta) at a rate of $760 \mathrm{~mL} \cdot \mathrm{ha}^{-1}$; Admire Pro (imidacloprid; Bayer Corp., Kansas City, MO) at a rate of $636 \mathrm{~mL} \cdot \mathrm{ha}^{-1}$, and Vydate C-LV (oxamyl; Du Pont, Wilmington, DE) at a rate of $5 \mathrm{~L} \cdot \mathrm{ha}^{-1}$ were applied in-row before covering the seeds pieces with soil. All other pesticide applications during the growing season followed University of Florida, Institute of Food and Agricultural Sciences Extension integrated pest management recommendations (Zotarelli et al., 2016). Preplant fertilizer application occurred $2 \mathrm{~d}$ before planting with a granular $5 \mathrm{~N}-4.4 \mathrm{P}-$ $12.45 \mathrm{~K}$ fertilizer blend at a rate of 1120 $\mathrm{kg} \cdot \mathrm{ha}^{-1}$ and banded ( $0.3 \mathrm{~m}$ width band) on the soil surface of each row and subsequently incorporated. The first sidedress fertilizer application of $15 \mathrm{~N}-0 \mathrm{P}-20.8 \mathrm{~K}$ fertilizer blend at a rate of $560 \mathrm{~kg} \cdot \mathrm{ha}^{-1}$ was performed at plant emergence around 25 DAP on 6 Feb. 2013, 10 Feb. 2014, and 2 Feb. 2016. About 40 DAP each year, the second sidedress of
$15 \mathrm{~N}-0 \mathrm{P}-0 \mathrm{~K}$ fertilizer blend was applied at a rate of $560 \mathrm{~kg} \cdot \mathrm{ha}^{-1}$ on $24 \mathrm{Feb} .2013$, 23 Feb. 2014, and 3 Mar. 2016. The sidedress application was banded and subsequently mechanically covered with soil.

Data collection and analysis. After plant emergence, 6-m-long sections at the two center rows of each subplot were marked for future harvest and quantification of yield. The two marked sections were harvested and evaluated individually. Air temperature, relative humidity, precipitation, solar radiation, and wind speed were obtained for the entire growing season each year from the Florida Automated Weather Network (www.fawn. ifas.ufl.edu). Tubers were harvested on 29 Apr. 2013, 8 May 2014, and 25 Apr. 2016. Following harvest, potatoes were washed and graded according to USDA standards into A4 (diameter $>10.2 \mathrm{~cm}$ ), A3 (diameter between 8.3 and $10.2 \mathrm{~cm}$ ), A2 (diameter between 6.4 and $8.29 \mathrm{~cm}$ ), A1 (diameter between 4.8 and $6.39 \mathrm{~cm}$ ), B (diameter between 3.8 and $4.79 \mathrm{~cm}$ ), and $\mathrm{C}$ (diameter between 1.3 and $3.79 \mathrm{~cm}$ ). Tubers were classified as marketable if they had a diameter of 4.8 to $10.2 \mathrm{~cm}$ according to USDA Standards for Grades of Potatoes for Chipping (USDA, 2011). Tubers with mechanical injuries, greening, decay, or misshapen were weighed and counted. A subsample of 20 marketable tubers was randomly selected from each plot and sliced cross-sectionally into quarter sections and then longitudinally for visual evaluation of brown center $(\mathrm{BC})$, hollow heart $(\mathrm{HH})$, internal heat necrosis (IHN), and other internal defects. $A \geq 2000 \mathrm{~g}$ subsample of marketable tubers was randomly selected for specific gravity according to the formula for specific gravity $=T \mathrm{a} /(T \mathrm{a}-T \mathrm{w})$, where $T \mathrm{a}$ is tuber weight in air and $T \mathrm{w}$ is tuber weight in water.

Data were analyzed using the PROC GLM and PROC REG procedures of SAS version 9.4 (SAS Institute Inc., Cary, NC). A two-way analysis of variance (ANOVA) was performed to determine the main effects of cultivar, seed piece spacing, and their interaction on total yield, marketable yield, internal tuber disorders, and specific gravity. Replicates for all trials were treated as random. Box plots and residuals were used to evaluate variance assumptions. There was a significant difference of year for the yield, specific gravity, and few internal quality parameters, thus the results from 2013, 2014, and 2016 seasons were analyzed separately. Means separation was used to examine differences between cultivar $\times$ seed piece spacing treatments when the interaction of the two main effects was significant. Regression analysis was used to determine if a linear or quadratic relationship existed for seed piece spacing treatments.

A partial budget analysis of seed piece spacing treatments was conducted for each of the 3 trial years. The $20 \mathrm{~cm}$ seed piece spacing was considered the control used for cost analysis. The amount of potato seed needed to plant 1 ha was calculated based on 9690 linear $\mathrm{m} \cdot \mathrm{ha}^{-1}$ (e.g., 13,068 linear $\mathrm{ft} / \mathrm{acre})$. Seed cost was estimated based on
Maine Farmers Exchange (MFX, Presque Isle, ME) 2015 current seed cost of $\$ 68.40$ per $100 \mathrm{~kg}$ (e.g., $\$ 15.5$ per $50 \mathrm{lb}$ ) for 'Atlantic'. The partial budget analysis for the chipping market counted the sellable tuber size classes as the summation of all $\mathrm{A}$ classes (A1-A4). Transportation costs were not considered in this partial budget analysis and should be considered on a location basis.

\section{Results and Discussion}

Overview of weather patterns. The performance of the potato crop was influenced by different weather conditions during the 3 years of this study. Minimum air temperatures below $0{ }^{\circ} \mathrm{C}$ occurred after plant emergence in 2013 crop season (Fig. 1). In that season, plants were mechanically covered on three occasions with a mound of soil (hilling) raising the soil to $\approx 7$ to $10 \mathrm{~cm}$ above the potato plant between planting and midMarch. Two freeze events occurred in 2014 and 2016 before plant emergence thus, no additional management was taken. Overall, air temperatures during the growing season were favorable for potato development in 2014 and 2016. Cumulative rainfall between planting and harvest in the 2013, 2014, and 2016 potato seasons was 202, 360, and $298 \mathrm{~mm}$, respectively. More than $90 \%$ of the rainfall in 2013 occurred after 55 DAP, after tuber initiation, and the last fertilizer application (Fig. 1). In 2014, $131 \mathrm{~mm}$ of cumulative rainfall occurred in February, which was considerably higher than the average rainfall for that region and month $(>87 \mathrm{~mm})$. This likely led to poor early plant growth but by May, plant growth appeared normal. In 2016, rainfall distribution was more uniform than the 2013 and 2014 growing seasons with only five rainfall events contributing more than $25 \mathrm{~mm}$ of precipitation during one event (Fig. 1).

Growing season comparisons. The Type III test of seed piece spacing and cultivar treatment effects on total and marketable yield, tuber size distribution, tuber internal quality, and specific gravity is presented in Table 1. Total and marketable yield was lower in 2013 compared with 2014 and 2016 (Fig. 2). The average total yield was 18.8, 30.7, and 27.3 Mg.ha ${ }^{-1}$ in 2013, 2014, and 2016, respectively. The lower total tuber yield in 2013 may be attributed to the series of freeze events after plant emergence between mid-February and mid-March (Fig. 1). Sprout development and elongation are temperature dependent and occur more rapidly between 17 and $20{ }^{\circ} \mathrm{C}$ than between 7 and $10{ }^{\circ} \mathrm{C}$ (Gudmestad, 2008). Furthermore, as mentioned earlier, plots were hilled with soil in 2013 to prevent frost damage and then mechanically uncovered using a disc implement once the threat of frost damage dissipated. The hilling operation resulted in observable mechanical damage to the canopy that likely affected the rate of sprout and root elongation. Together, the low air temperatures and hilling negatively interfered with crop establish in 2013. In 2014, excess rain in 


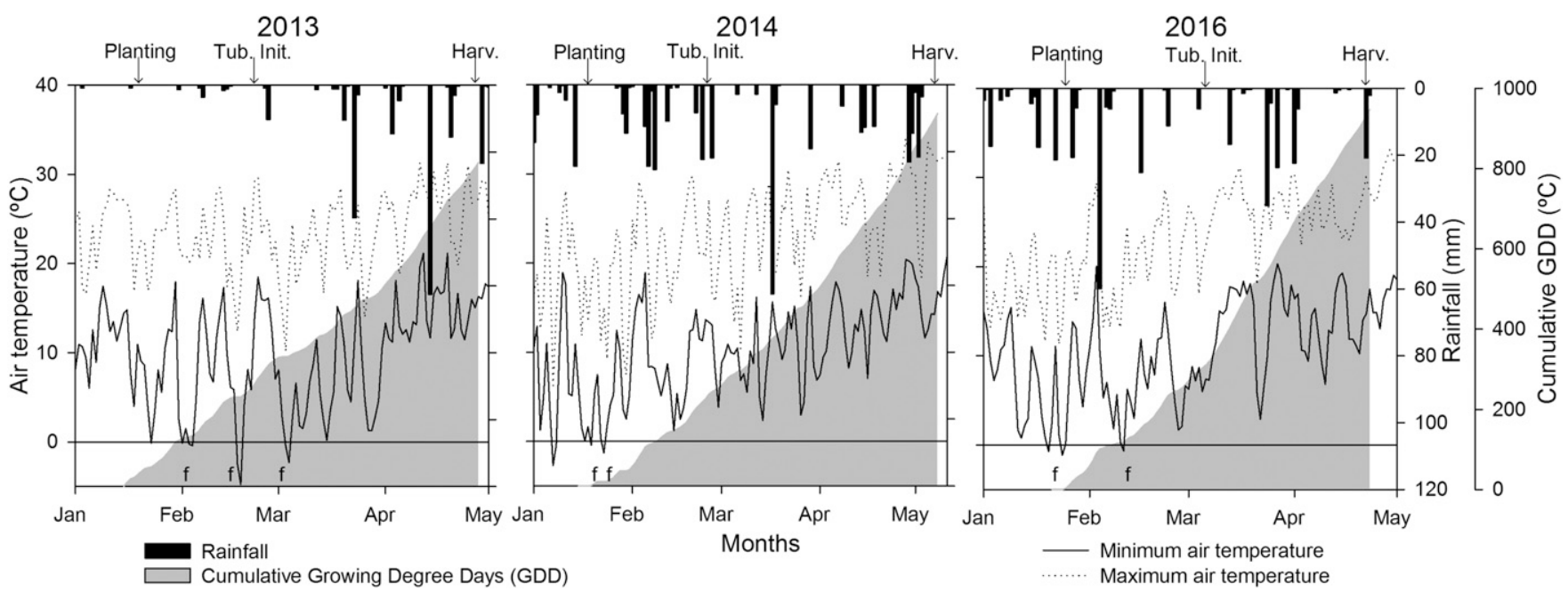

Fig. 1. Minimum and maximum air temperatures at $60 \mathrm{~cm}$ height, total rainfall $(\mathrm{mm})$, freezing events (f), and cumulative growing degree-days (GDD) during the potato growing season in 2013, 2014, and 2016 in Hastings, FL. Data from Florida Automated Network (FAWN).

Table 1. Type III test for seed piece spacing and potato cultivars for total and marketable yield, tuber size distribution, internal quality, and specific gravity.

\begin{tabular}{|c|c|c|c|c|c|c|c|c|c|c|c|c|c|}
\hline \multirow[b]{2}{*}{ Main effect } & \multirow[b]{2}{*}{$\mathrm{df}$} & \multicolumn{2}{|c|}{ Yield $\left(\mathrm{Mg} \cdot \mathrm{ha}^{-1}\right)$} & \multicolumn{6}{|c|}{ Size distribution $^{z}$} & \multicolumn{3}{|c|}{ Internal quality ${ }^{y}$} & \multirow[b]{2}{*}{ Specific gravity } \\
\hline & & Total & Marketable & $\overline{\mathrm{A} 1}$ & $\mathrm{~A} 2$ & $\mathrm{~A} 3$ & A4 & $\mathrm{B}$ & $\bar{C}$ & $\overline{\mathrm{HH}}$ & IHN & $\overline{\mathrm{BCL}}$ & \\
\hline Block & 3 & & & & & & & & & & & & \\
\hline Cultivar (C) & 2 & $* *$ & $* * *$ & $*$ & $* * *$ & $* * *$ & NS & $* * *$ & $* * *$ & NS & $*$ & $* * *$ & $* * *$ \\
\hline $\mathrm{S} \times \mathrm{C}$ & 8 & NS & NS & NS & NS & NS & NS & NS & $* * *$ & NS & NS & NS & NS \\
\hline \multicolumn{14}{|l|}{2014} \\
\hline Block & 3 & & & & & & & & & & & & \\
\hline $\mathrm{S} \times \mathrm{C}$ & 8 & NS & NS & NS & NS & NS & NS & NS & NS & NS & NS & NS & NS \\
\hline \multicolumn{14}{|l|}{2016} \\
\hline Block & 3 & & & & & & & & & & & & \\
\hline Spacing (S) & 4 & *** & $* * *$ & $* * *$ & $* * *$ & $* * *$ & NS & $* * *$ & $* * *$ & NS & NS & NS & NS \\
\hline Cultivar (C) & 2 & $* *$ & $* * *$ & $* *$ & $* *$ & $* *$ & NS & $*$ & $* * *$ & $* *$ & NS & NS & $* * *$ \\
\hline $\mathrm{S} \times \mathrm{C}$ & 8 & NS & NS & NS & NS & NS & NS & NS & NS & NS & NS & NS & NS \\
\hline
\end{tabular}

${ }^{\mathrm{z}}$ Tuber size distribution: A4 $(>10.2 \mathrm{~cm}), \mathrm{A} 3(8.3-10.2 \mathrm{~cm})$, A2 $(6.4-8.29 \mathrm{~cm}), \mathrm{A} 1(4.8-6.39 \mathrm{~cm}), \mathrm{B}(3.8-4.79 \mathrm{~cm}), \mathrm{C}(1.3-3.79 \mathrm{~cm})$.

${ }^{\mathrm{y}}$ Internal quality parameters: $\mathrm{HH}=$ hollow heart; $\mathrm{IHN}=$ internal heat necrosis; $\mathrm{BCL}=$ brown center light.

Ns, $*, * *, * * *$ Nonsignificant or significant at $P \leq 0.05,0.01$, or 0.001 , respectively.

the month of February (131 mm) likely reduced the rate of crop growth and development. With the adverse growing conditions observed in 2013 and 2014, the treatments with narrower seed piece spacings (e.g., 10 and $15 \mathrm{~cm}$ ) had higher total yields compared with the wider seed piece spacing treatments. A similar trend of higher total tuber yields with narrow spacing was not reported in 2016 under more favorable weather conditions for potato growth (Fig. 2).

Tuber yield and size distribution. There was no significant interaction between seed piece spacing and cultivar for total and marketable yield in any year; however, cultivar and seed piece spacing significantly affected total and marketable yield in all three seasons (Table 1). In 2013 and 2014, there was a linear decrease in total and marketable yield with widening seed piece spacing (Table 2), which was in agreement with previous studies (Arsenault et al., 2001; DeBuchananne and Lawson, 1991; Love and Thompson-Johns, 1999; Rex, 1990). However, the narrower seed piece spacings did not result in higher marketable yields consistently across years. In 2016, there was a positive relationship for total and marketable yield as seed piece spacing increased (Table 2). The $\mathrm{B}$ and $\mathrm{C}$ tuber size classes are considered unmarketable for chipping processing. In 2013, the proportion of unmarketable yield was $38 \%$ and $36 \%$ and in $2014,65 \%$ and $62 \%$ for $10-$ and $15-\mathrm{cm}$ treatments, respectively (Fig. 2). In 2016, $\approx 62 \%$ and $48 \%$ of the total yield were unmarketable for the 10 and $15 \mathrm{~cm}$ seed piece spacing, respectively.

Increased tuber yield at low plant populations was reported by Mangani et al. (2015). In that study, the three potato cultivars (BP1, KY20, and Mnandi) planted at $30 \mathrm{~cm}$ seed piece spacing produced 2.6 to $5.4 \mathrm{Mg} \cdot \mathrm{ha}^{-1}$ more tubers than the $20 \mathrm{~cm}$ seed piece spacing. In the present study, there was a significant increase in $\mathrm{A} 2$ and $\mathrm{A} 3$ tuber sizes in 2013 and 2016 and an increase of A1 tubers in 2016 with the increase of seed piece spacing (Table 3). In 2013, there was an interaction between seed piece spacing and cultivar for tuber size class C $(1.3-3.8 \mathrm{~cm})$. The amount of tubers classified as C in 2013 ranged between 217 and $850 \mathrm{~kg} \cdot \mathrm{ha}^{-1}$, which represented $2 \%$ to $5 \%$ of the overall marketable yield in 2013. The amount of tubers classified as $\mathrm{C}$ was significantly higher for cultivar Harley Blackwell compared with Atlantic and Elkton under seed piece spacings of 10 and $15 \mathrm{~cm}$.

The marketplace demands different tuber sizes according to the purpose of use. Seed markets prefer small size tubers, whereas processing market prefers larger tubers. Love and Thompson-Johns (1999) and Khalafalla (2001) evaluated in-row seed piece spacings ranging from 8 to $91 \mathrm{~cm}$ and 15 to $35 \mathrm{~cm}$, respectively. Both studies showed that closer spacing resulted in higher quantity of smaller tubers. In the current study, the ratio of smallsized tubers (B and C) increased at narrower seed piece spacings with A1-sized tubers were the most abundant across years and seed piece spacing. In addition, A2- and A3-sized tubers increased with a decrease in plant density in all 3 years (Fig. 2). It is important to note that total and marketable tuber yield (A1-A4) of the Florida industry standard seed piece spacing $(20 \mathrm{~cm})$ was not 

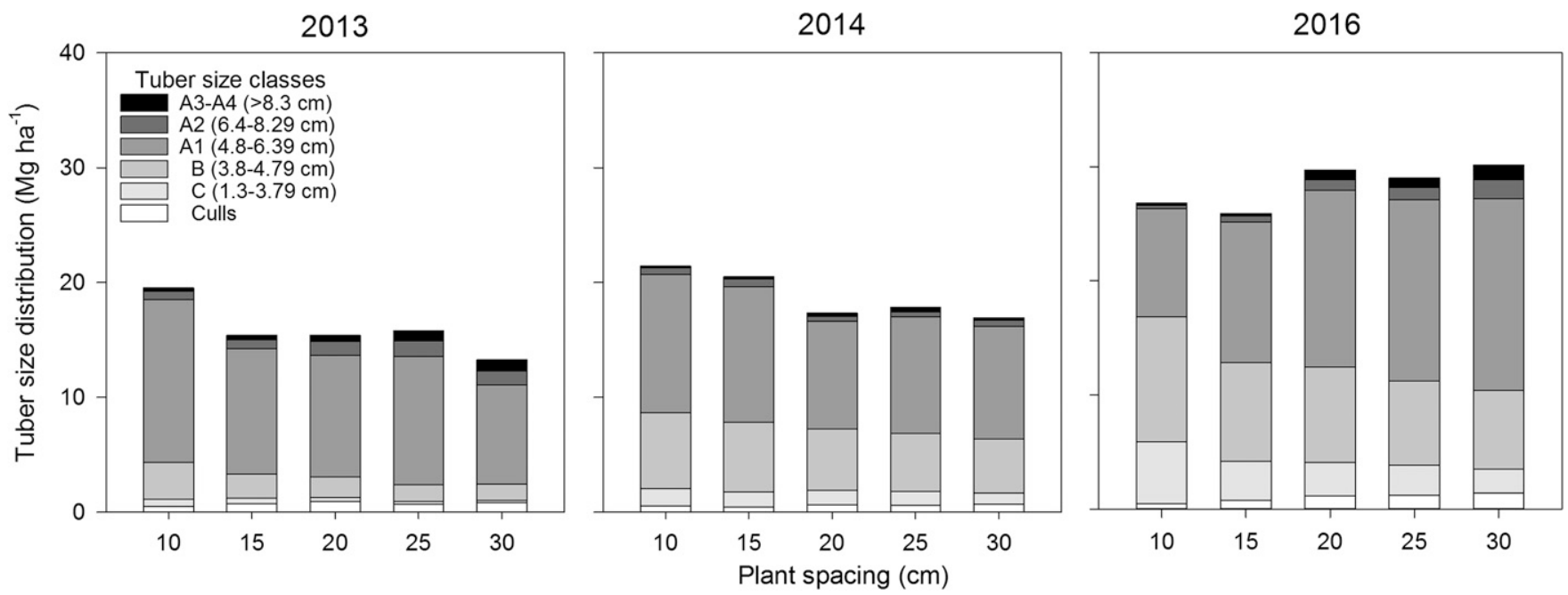

Fig. 2. Tuber size distribution potatoes planted at 10, 15, 20, 25, and $30 \mathrm{~cm}$ seed piece spacing in the spring of 2013, 2014, and 2016.

Table 2. Linear regression between yield (tuber total and marketable yield and marketable yield breakdown into several tuber size classes) and seed piece spacing for potato growing season in 2013, 2014, and 2016 in Hastings, FL.

\begin{tabular}{ll}
\hline Total yield & \multicolumn{1}{c}{ Linear regression $\left(\mathrm{Mg} \cdot \mathrm{ha}^{-1}\right)$} \\
\hline 2013 & $Y_{\text {total }}=26,762-392.999^{*} \mathrm{sp}, R^{2}=0.36$ \\
2014 & $Y_{\text {total }}=39,985-463.953 * \mathrm{sp}, R^{2}=0.35$ \\
2016 & $Y_{\text {total }}=24,366+146.387 * \mathrm{sp}, R^{2}=0.11$ \\
Marketable yield & $Y_{\text {marketable }}=20,202-253.748 * \mathrm{sp}, R^{2}=0.20$ \\
2013 & $Y_{\text {marketable }}=23,052-242.070 * \mathrm{sp}, R^{2}=0.12$ \\
2014 & $Y_{\text {marketable }}=5,850+430.975 * \mathrm{sp}, R^{2}=0.48$ \\
2016 & $Y_{\mathrm{A} 1}=15,442-216.836 * \mathrm{sp}, R^{2}=0.22$ \\
$\mathrm{~A} 1(4.8-6.4 \mathrm{~cm})$ & $Y_{\mathrm{A} 1}=6,703+365.135 * \mathrm{sp}, R^{2}=0.43$ \\
2013 & \\
2016 & $Y_{\mathrm{A} 2}=400+32.957 * \mathrm{sp}, R^{2}=0.09$ \\
$\mathrm{~A} 2(6.4-8.3 \mathrm{~cm})$ & $Y_{\mathrm{A} 2}=-405+66.254 * \mathrm{sp}, R^{2}=0.36$ \\
2013 & \\
2016 & $Y_{\mathrm{A} 3}=-134+35.982 * \mathrm{sp}, R^{2}=0.15$ \\
$\mathrm{~A} 3(8.3-10.2 \mathrm{~cm})$ & $Y_{\mathrm{A} 3}=-411+52.133 * \mathrm{sp}, R^{2}=0.26$ \\
2013 & \\
2016 & $Y_{\mathrm{A} 1-3}=15,714-147.896 * \mathrm{sp}, R^{2}=0.08$ \\
$\mathrm{~A} 1+\mathrm{A} 2+\mathrm{A} 3(4.8-10.2 \mathrm{~cm})$ & $Y_{\mathrm{A} 1-3}=5,870+484.591 * \mathrm{sp}, R^{2}=0.51$ \\
2013 & $Y_{\mathrm{B}}=3,691-85.597 * \mathrm{sp}, R^{2}=0.52$ \\
2016 & $Y_{\mathrm{B}}=7,468-95.384 * \mathrm{sp}, R^{2}=0.38$ \\
$\mathrm{~B}(3.8-4.8 \mathrm{~cm})$ & $Y_{\mathrm{B}}=12,247-189.834 * \mathrm{sp}, R^{2}=0.11$ \\
2013 & \\
2014 & $Y_{\mathrm{C}}=796-20.255^{*} \mathrm{sp}, R^{2}=0.48$ \\
2016 & $Y_{\mathrm{C}}=1,714-23.620^{*} \mathrm{sp}, R^{2}=0.17$ \\
$\mathrm{C}(1.3-3.8 \mathrm{~cm})$ & $Y_{\mathrm{C}}=6,278-148.370 * \mathrm{sp}, R^{2}=0.49$ \\
2013 & \\
2014 & \\
2016 &
\end{tabular}

Table 3. Incidence of hollow heart, internal heat necrosis, and brown center in Atlantic, Elkton, and Harley Blackwell.

\begin{tabular}{|c|c|c|c|c|c|c|}
\hline \multirow[b]{2}{*}{ Cultivar } & \multicolumn{2}{|c|}{ Hollow heart } & \multicolumn{2}{|c|}{$\begin{array}{c}\text { Internal heat } \\
\text { necrosis }\end{array}$} & \multicolumn{2}{|c|}{ Brown center } \\
\hline & 2014 & 2016 & 2013 & 2014 & 2013 & 2014 \\
\hline & & & & & & \\
\hline Atlantic & $4.3 \mathrm{a}$ & $1.38 \mathrm{a}$ & $1.3 \mathrm{a}$ & $3.1 \mathrm{a}$ & $2.75 \mathrm{a}$ & $10.4 \mathrm{a}$ \\
\hline Harley Blackwell & $1.9 \mathrm{~b}$ & $0.13 \mathrm{~b}$ & $0.5 \mathrm{ab}$ & $0.4 \mathrm{~b}$ & $0.25 \mathrm{~b}$ & $1.1 \mathrm{~b}$ \\
\hline Elkton & $1.4 \mathrm{~b}$ & $0.00 \mathrm{~b}$ & $0.0 \mathrm{~b}$ & $0.3 \mathrm{~b}$ & $0.25 \mathrm{~b}$ & $0.5 \mathrm{~b}$ \\
\hline
\end{tabular}

Values followed by the same lowercase letter indicate that the means are not significantly different $(P<$ 0.05 ) according to Tukey's test within the same year.

significantly different from the $25 \mathrm{~cm}$ seed piece spacing for all growing seasons.

In general, cultivars performed variably in regard to each other across years. Elkton

HortScience Vol. 52(2) February 2017 outperformed Atlantic and Harley Blackwell for total and marketable yield in 2013, with no significant differences between Atlantic and Harley Blackwell (Fig. 3). In 2014, total yield was higher for Harley Blackwell and Elkton than Atlantic. For marketable yield in 2014, Harley Blackwell yielded significantly more marketable tubers than Atlantic. In 2016, total yield for Atlantic was significantly higher than Elkton but Atlantic had significantly higher marketable yield compared to both Elkton and Harley Blackwell (Fig. 3). Considering there was no cultivar by seed piece spacing interaction for total yield, marketable yield, and size distribution of tubers, except for C size class in 2013, all cultivars tested performed similarly under each seed piece spacing treatment.

Internal tuber disorders. In the present study, seed piece spacing had no significant effect on the percentage of internal tuber disorders. This corroborates previous findings (Rex, 1990) where seed piece population had no effect on hallow heart $(\mathrm{HH})$. However, cultivar was a significant source of variation for $\mathrm{HH}$ in 2014 and 2016 as well as for IHN and BC in 2013 and 2014 (Table 3). In all instances, significantly greater incidences of $\mathrm{HH}$ and $\mathrm{BC}$ were observed with Atlantic compared with Elkton and Harley Blackwell. For IHN, Atlantic exhibited a significantly higher percentage of incidences than Elkton in 2013 and 2014 and Harley Blackwell in 2014. There were no significant differences observed between Elkton and Harley Blackwell for incidence of $\mathrm{HH}, \mathrm{IHN}$, and BC in any year. Cultivar descriptions of Elkton and Harley Blackwell discuss their resistant to IHN (Haynes et al., 2014).

Specific gravity. Seed piece spacing significantly affected specific gravity (e.g., solid content of the potato) in 2013 alone (Table 1). The seed piece spacing of 10,15 , and $20 \mathrm{~cm}$ had specific gravity of 1.066 , whereas 25 and $30 \mathrm{~cm}$ spacings had specific gravities of 1.067 and 1.068 , respectively. Although there was a significant difference between the seed piece spacing treatments for specific gravity in 2013, linear or quadratic models were not significant for this parameter (data not 

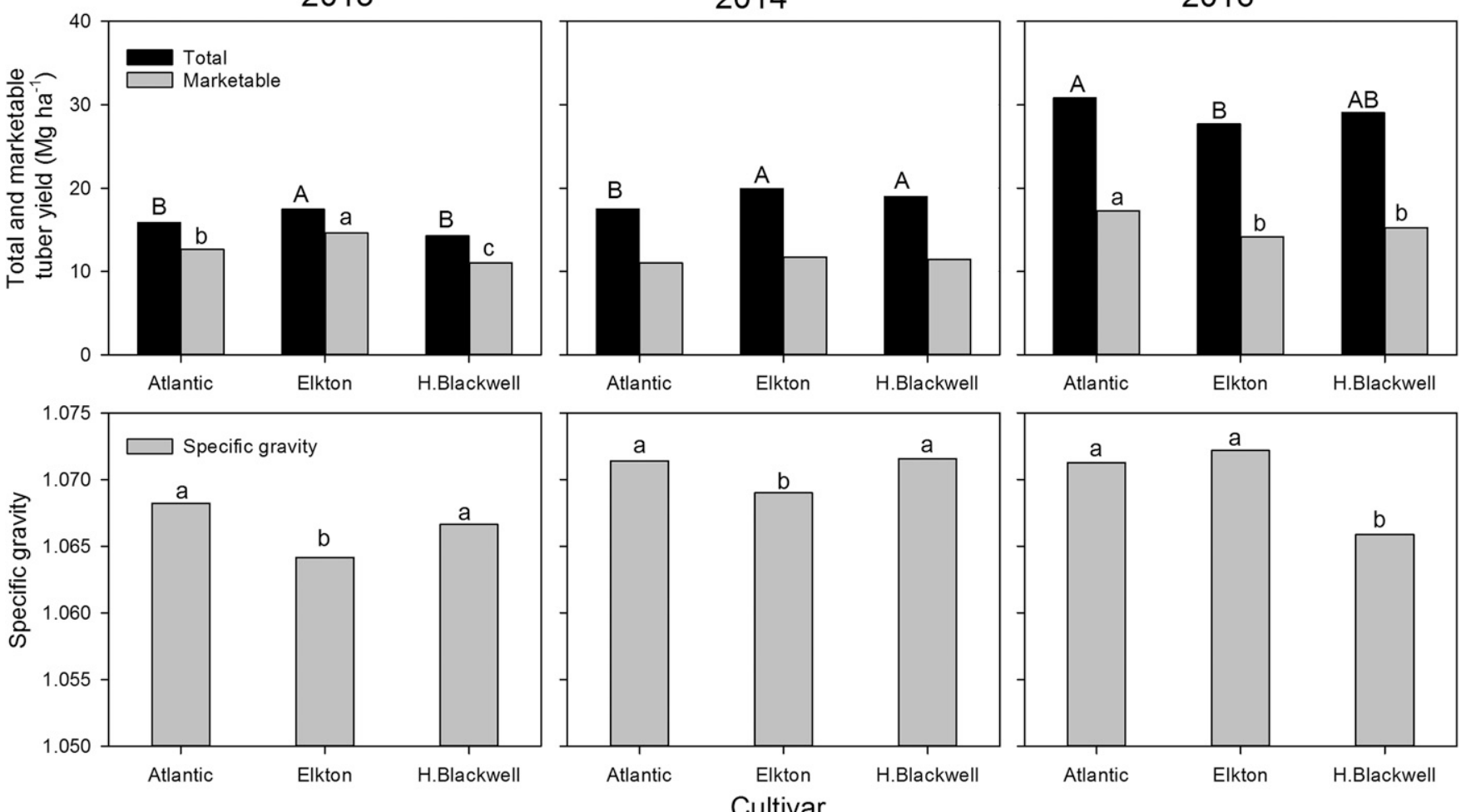

Fig. 3. Total and marketable tuber yield $\left(\mathrm{Mg}_{\mathrm{h}} \mathrm{ha}^{-1}\right)$ of Atlantic, Harley Blackwell, and Elkton averaged across five seed piece spacings in Hastings, FL, in the spring of 2013, 2014, and 2015 (upper graphs). Tuber specific gravity of Atlantic, Harley Blackwell, and Elkton averaged across five seed piece spacings (lower graphs). Means followed by the same letter are not significantly different at $P<0.05$ according to Tukey's test within each year.

Table 4. Total yield, marketable yield, and net revenue for $56 \mathrm{~g}$ seed piece for Atlantic, Elkton, and Harley Blackwell planted at 10, 15, 20, 25, and 30 cm seed piece spacings in 2013, 2014, and 2016 growing seasons in Hastings, FL.

\begin{tabular}{|c|c|c|c|c|c|c|}
\hline & \multicolumn{2}{|c|}{ Yield $\left(\mathrm{Mg} \cdot \mathrm{ha}^{-1}\right)$} & \multirow[b]{2}{*}{ Seed cost (\$ per hectare) } & \multicolumn{3}{|c|}{ Estimated net revenue $(\$ \text { per } 100 \mathrm{~kg})^{2}$} \\
\hline & Total & A's tuber size class & & 24.3 & 26.5 & 28.7 \\
\hline \multicolumn{7}{|c|}{ Seed piece spacing $(\mathrm{cm})$} \\
\hline \multicolumn{7}{|l|}{2013} \\
\hline 15 & 15.37 & 12.05 & 2,502 & 426 & 691 & 956 \\
\hline 20 & 15.37 & 12.30 & 1,876 & 1,113 & 1,384 & 1,654 \\
\hline 25 & 15.78 & 13.40 & 1,501 & 1,755 & 2,050 & 2,345 \\
\hline 30 & 13.26 & 10.84 & 1,251 & 1,383 & 1,622 & 1,860 \\
\hline 10 & 21.41 & 12.76 & 3,753 & -652 & -372 & -91 \\
\hline 15 & 20.52 & 12.69 & 2,502 & 582 & 861 & 1,140 \\
\hline 20 & 17.33 & 10.08 & 1,876 & 573 & 795 & 1,017 \\
\hline 25 & 17.80 & 10.95 & 1,501 & 1,160 & 1,401 & 1,642 \\
\hline 30 & 16.92 & 10.55 & 1,251 & 1,313 & 1,545 & 1,777 \\
\hline LSD $(0.05)$ & 1.46 & 1.37 & - & - & - & - \\
\hline \multicolumn{7}{|l|}{2016} \\
\hline 30 & 30.99 & 19.73 & 1,251 & 3,543 & 3,977 & 4,412 \\
\hline $\operatorname{LSD}(0.05)$ & 1.83 & 1.86 & - & - & - & - \\
\hline
\end{tabular}

${ }^{\mathrm{z}}$ Net revenue $=$ expected gross revenue per hectare - cost of the seed per hectare.

$\mathrm{y}_{\text {LSD }}$, least significant difference at $P \leq 0.05$.

shown). Previous research has shown no relationship between seed piece spacing and specific gravity in potato (Rex, 1990; Timm et al., 1963) supporting what was observed in 2014 and 2016 in the current study.

There were significant differences in specific gravity for the tested cultivars in all 3 years (Table 1). In 2013, specific gravity in
Elkton was 0.004 and 0.003 lower than Atlantic and Harley Blackwell, respectively (Fig. 3). In 2014, specific gravity of Harley Blackwell and Atlantic was significantly higher than Elkton. In 2016, specific gravity of Atlantic and Elkton was significantly higher than Harley Blackwell (Fig. 3). The low tuber specific gravity for Elkton and
Harley Blackwell was expected. Previous studies conducted for multiple years in Florida reported that the specific gravity of Elkton and Harley Blackwell has been 0.002 and 0.006 lower than in Atlantic, respectively (Haynes et al., 2014; USDA, 2016). There is a well-documented positive correlation between tuber dry mater percentage and 
specific gravity (Schippers, 1976). Furthermore, specific gravity is important to the processing industry in terms of finished product yield and quality for the chips and fries (Lulai and Orr, 1979). A positive linear relationship between specific gravity and chip yield has been observed with the cultivar Norchip (Lulai and Orr, 1979). Furthermore, with every 0.005 increase in specific gravity, the number of potato chips that are processed from $100 \mathrm{lbs}$ of raw potatoes increases by $1 \mathrm{lb}$ (Gould, 1999).

Partial budget analysis. Since more potato seed was required per unit area when narrower seed piece spacings were used, seed piece spacing proportionally increased cost. In the case of narrow seed spacings (10 or 15 $\mathrm{cm}$ ), production may become less costeffective due to potato seed expenditures. Transportation, storage, and management costs were not considered in this partial budget analysis because the objective of this analysis was to determine only the effect of seed piece spacing on net revenue.

The net revenue based on variable contract/selling price for tuber size above $4.8 \mathrm{~cm}$ diameter (A classes) is shown in Table 4. In all three seasons, wider seed piece spacings $(25$ and $30 \mathrm{~cm}$ ) showed higher revenues than the standard $20 \mathrm{~cm}$ spacing (Table 4). Likewise in all three seasons, a $29 \%$ to $37 \%$ higher net revenue was obtained by widening the seed piece spacing from 20 to $25 \mathrm{~cm}$, depending on the selling price. In 2013, the highest economic return was reached with the $25 \mathrm{~cm}$ spacing, while in 2014 and 2016, the $30 \mathrm{~cm}$ seed piece spacing treatment was the most profitable. Seed piece spacings of 10 and $15 \mathrm{~cm}$ showed a reduction in revenues compared with the wider spacings. Although the 10 and $15 \mathrm{~cm}$ seed piece spacings produced significantly higher A class size tuber yield than the $25 \mathrm{~cm}$ spacing in 2013 and 2014, the higher cost of seed reduced the revenues for those spacings. In fact, in 2014 and 2016, the $10 \mathrm{~cm}$ spacing resulted in revenue loss regardless of the contract prices. Although revenues vary from year to year, depending on contract price and yield, the present study suggests that higher revenues may be obtained by widening the potato seed piece spacing from the commercial standard of $20 \mathrm{~cm}$ to 25 or $30 \mathrm{~cm}$.

\section{Conclusion}

There were considerable differences in growing conditions across the 2013, 2014, and 2016 seasons. The 2013 season had poor growing conditions compared with 2014 and 2016 because of freezing events, which likely contributed to lower total and marketable yields. A negative linear relationship was observed between total and marketable yield with seed piece spacing in the less favorable seasons of 2013 and 2014; however, potato yields significantly increased with increase in seed piece spacing in 2016. There was no significant seed piece spacing by cultivar interactions for total yield, marketable yield, size distribution of tubers (except 2013 for the smallest tuber size class), internal quality of tubers, or specific gravity in any year. Both spacing and cultivar significantly affected total yield, marketable yield, and size distribution of tubers for most of the size classes and years; however; spacing had no significant effect on specific gravity or internal tuber quality in 2014 or 2016. Cultivars responded variably across years for total yield, marketable yield, and specific gravity; Atlantic exhibited a higher incidence of tuber internal quality issues for $\mathrm{HH}$, IHN, and BCL compared with Elkton and Harley Blackwell. The partial budget analysis based on marketable yield, cost of seed, and net revenue determined by contract/selling prices paid to the growers demonstrated that the $25 \mathrm{~cm}$ spacing provided the greatest net revenue return in 2013 and the $30 \mathrm{~cm}$ spacing provided the greatest return in 2014 and 2016 . Considering the $20 \mathrm{~cm}$ is the industry standard seed piece spacing for chipping and there were no significant differences in total or marketable yield between the 20 and $25 \mathrm{~cm}$ spacings any year, it is justifiable to suggest that net revenue can be increased by adjusting seed spacing from 20 to $25 \mathrm{~cm}$ without negatively impacting yield.

\section{Literature Cited}

Arsenault, W.J., D.A. Leblanc, G.C. Tai, and P. Boswall. 2001. Effects of nitrogen application and seed piece spacing on yield and tuber size distribution in eight potato cultivars. Amer. J. Potato Res. 78:301-309.

Bohl, W.H., J.C. Stark, and C.S. Mcintosh. 2011. Potato seed piece size, spacing, and seeding rate effects on yield, quality and economic return. Amer. J. Potato Res. 88:470-478.

Bussan, A.J., P.D. Mitchell, M.E. Copas, and M.J. Drilias. 2007. Evaluation of the effect of density on potato yield and tuber size distribution. Crop Sci. 47:2462-2472.

Creamer, N., C. Crozier, and M. Cubeta. 1999 Influence of seed piece spacing and population on yield, internal quality, and economic performance of Atlantic, Superior, and Snowden potato varieties in eastern North Carolina. Amer. J. Potato Res. 76:257-261.

DeBuchananne, D.A. and V.F. Lawson. 1991. Effect of plant population and harvest timing on yield and chipping quality of Atlantic and Norchip potatoes at two Iowa locations. Amer. Potato J. 68:287-297.

Gould, W.A. 1999. Specific gravity of potatoes, $p$ 51-72. In: W.A. Gould (ed.). Potato production, processing and technology. CIT Publications, Timonium, MD.

Gudmestad, N.C. 2008. Potato health from sprouting to harvest, p. 67-78. In: D.A. Johnson (ed.) Potato health management. American Phytopathological Society, St. Paul, MN.

Haynes, K.G., D.M. Gergela, X.S. Qu, M.W. Peck, G.C. Yencho, M.E. Clough, M.R. Henninger, D.E. Halseth, G.A. Porter, P.C. Ocaya, L. Zotarelli, S.R. Menasha, B.J. Christ, L. Wanner, and C.M. Hutchinson. 2014. Elkton:
A new potato variety with resistance to internal heat necrosis and hollow heart and suitable for chipping directly from the field in the southern United States. Amer. J. Potato Res. 91:269276.

Hutchinson, C.M., D.M. Gergela, D.A. Dinkins, and E.E. Redden. 2006. Harley Blackwell'a new chip stock potato variety for Florida. Proc. Annu. Meet. Fla. State Hort. Soc. 119:279-281.

Khalafalla, A.M. 2001. Effect of plant density and seed size on growth and yield of solanum potato in Khartoum State, Sudan. Afr. Crop Sci. J. 9:77-82.

Love, S.L. and A. Thompson-Johns. 1999. Seed piece spacing influences yield, tuber size distribution, stem and tuber density, and net returns of three processing potato cultivars. HortScience 34:629-633.

Lulai, E.C. and P.H. Orr. 1979. Influence of potato specific gravity on yield and oil content of chips. Amer. Potato J. 56:379-390.

Mangani, R., U. Mazarura, T.A. Mtaita, and A. Shayanowako. 2015. Growth, yield and quality responses to plant spacing in potato (Solanum tuberosum) varieties. Afr. J. Agr. Res. 10:571578.

Rex, B.L. 1990. Effect of seed piece population on the yield and processing quality of Russet Burbank potatoes. Amer. Potato J. 67:473-489.

Schippers, P.A. 1976. The relationship between specific gravity and percentage dry matter in potato tubers. Amer. Potato J. 53:111-122.

Timm, H., J. Bishop, and V. Schweers. 1963. Growth, yield, and quality of White Rose potatoes as affected by plant population and levels of nitrogen. Amer. J. Potato Res. 40:182-192.

U.S. Department of Agriculture (USDA). 1983. Soil Survey of St. Johns County, Florida. Natural Resources Conservation Service, U.S. Department of Agriculture. $24 \mathrm{Feb}$. 2015. <http://www.nrcs.usda.gov/Internet/ FSE_MANUSCRIPTS/florida/FL109/0/StJohns. pdf $>$.

U.S. Department of Agriculture (USDA). 2011. United States standards of grades of potato. 23 Sept. 2015. $<$ https://www.ams.usda.gov/sites/default/files/ media/Potato_Standard\%5B1\%5D.pdf>.

U.S. Department of Agriculture (USDA). 2015. Florida Agricultural Overview. USDA's National Agricultural Statistics Service. 22 Feb. 2015. <http://www.nass.usda.gov/Quick Stats/Ag_Overview/stateOverview.php?state $=$ FLORIDA>.

U.S. Department of Agriculture (USDA). 2016. Naming and release of the Harley Blackwell potato variety. $20 \mathrm{Sep} 2016$. <https://www.ars. usda.gov/northeast-area/beltsville-md/beltsvilleagricultural-research-center/genetic-improvementfor-fruits-vegetables-laboratory/docs/potatoesharley-blackwell/>.

Webb, R.E., D.R. Wilson, J.R. Shumaker, B. Graves, M.R. Henninger, J. Watts, J.A. Frank, and H.J. Murphy. 1978. Atlantic: A new potato variety with high solids, good processing quality, and resistance to pests. Amer. J. Potato Res. 55:141-145.

Zotarelli, L., P.J. Dittmar, P.D. Roberts, and S.E. Webb. 2016. Potato production, p. 233-251. In: J. Dittmar, J.H. Freeman, and G.E. Vallad (eds.). Vegetable production handbook of Florida. Vance Publishing, Lincolnshire, IL. 